\title{
REFLECTING ON THE BRINGING THEM HOME REPORT
}

\author{
Anna Haebich
}

\section{Introduction ${ }^{1}$}

Bringing Them Home: Report of the National Inquiry into the Separation of Aboriginal and Torres Strait Islander Children from their Families (Bringing Them Home Report) ${ }^{2}$ was released in 1997. It represented a crucial breakthrough in exposing the system of forced removals and placements of Aboriginal and Torres Strait Islander children from colonial times to the present, across all Australian colonies, states and territories. The report caused an unprecedented outpouring of public shock, grief and shame that was followed by counter-attacks on the veracity of the findings, igniting one of the nation's most emotional and toxic public debates. This is all well known to us, or is it? 20 years on, it is time for Australians to join with members of the Stolen Generations and their families in assessing the nation's response to the report's findings and its 54 recommendations. In this essay I reflect on the backstory and reception of the report, the remembering and forgetting of what happened, and the continued fragmenting of Aboriginal and Torres Strait Islander families in the present day.

\section{Recalling the Bringing Them Home Report}

The Bringing Them Home Report was destined for controversy on several counts. The nation was rocked by its findings of an endemic system of forced child removals and placements in institutions, foster homes, adoptive families

\footnotetext{
1 This essay draws on my own research, in particular: Anna Haebich, "Indigenous Child Removal and Settler Colonialism: An Historical Overview,” Australian Indigenous Law Review 19, no. 1 (2015), 20-31; Anna Haebich, “Forgetting Indigenous Histories: Cases from Australia’s Stolen Generations,” Journal of Social History 44, no. 4 (2011), 1034-43, 1035.

2 Human Rights and Equal Opportunity Commission, Bringing Them Home: Report of the National Inquiry into the Separation of Aboriginal and Torres Strait Islander Children from their Families (Canberra: Human Rights and Equal Opportunity Commission, 1997).
} 
and forced employment, and the extent of the system through time and in all states and colonies:

Nationally we can conclude with confidence that between one in three and one in ten Indigenous children were forcibly removed from their families and communities in the period from approximately 1910 until 1970. In certain regions and in certain periods the figure was undoubtedly much greater than one in ten. In that time not one Indigenous family has escaped the effects of forcible removal (confirmed by representatives of the Queensland and WA Governments in evidence to the Inquiry). Most families have been affected, in one or more generations, by the forcible removal of one or more children. ${ }^{3}$

The findings revealed systematic racial discrimination, practised by targeting children of mixed descent. This system did not reflect the standards and practices legislated by state governments to protect the best interests of children. Evidence from over 500 testimonies showed forced removal and the emotional, physical and sexual abuse of children who were denied family, language, culture, country and their sense of identity and belonging. The transgenerational legacy for individuals, families and communities was presented in stories told to the Inquiry of family breakdown, ongoing medical, psychological and emotional problems, addictive behaviours, incarceration, violence, self-harm and suicide.

Sympathisers shed genuinely felt tears, made their apologies, and called for a national apology to ensure a safe future for Aboriginal and Torres Strait Islander children and families. A people's movement emerged, expressed in the advent of an annual national Sorry Day on May 26, and public signings of Sorry Books occurred, while Journeys of Healing and reconciliation marches in major cities were undertaken. Given the depth of public sorrow, it is painful to read Tony Birch's troubling observations on the passing nature of non-Aboriginal responses to the Bringing Them Home Report. Birch writes that:

a reaction for and of the moment allowed "colonial listeners confronted with a narrative of their own violence . . . to simultaneously absorb and purge themselves of trauma." This outcome lacks the ethic of responsibility, reflecting Slavoj Žižek's observation that "in order to forget an event, we must first summon up the strength to remember it properly."

3 Human Rights, Bringing Them Home, 30. 
Meanwhile, Birch continues, Indigenous communities were left to "carry alone the burden of being left to live with the sense of injustice" and the weighty responsibility of remembering the past. ${ }^{5}$

Remembering "properly" became increasingly difficult in the vitriolic public debate that emerged. Media reports of attacks on the credibility of the Bringing Them Home Report began to eclipse accounts of public goodwill. Denialists questioned the primacy and authority given by the Inquiry to the truths of Indigenous testimony as the official voice of Stolen Generations history. They challenged the credibility of evidence not given under oath and claimed witnesses were repeating circulating variations of a "constructed Stolen Generations narrative” originating in research conducted in the 1980s by historian Peter Read. ${ }^{6}$ The newly-elected conservative Prime Minister, John Howard, had reluctantly inherited the Report, introduced by the Keating Labor government in 1995. Howard allowed the critics free reign and, with his ministers, openly supported claims that children were rescued from physical and moral danger, and treated humanely by standards of the time. He rejected any generational responsibility for practices sanctioned by previous governments. Some accused Howard of playing the race card to denigrate the report and split the nation. Whatever his immediate political purpose, the lasting effect was to create a culture of denial and recrimination that irrevocably disfigured public debate on the issue.

The report's use of the language of international human rights and genocide served to further polarise public debate. United Nations instruments included in the report are the "Declaration of Human Rights" and the "International Convention on the Elimination of All Forms of Racial Discrimination”; the "Basic Principles and Guidelines on the Right to a Remedy and Reparation for Victims of Gross Violations of International Human Rights Law and Serious Violations of International Humanitarian Law” ("van Boven Principles"); and the "Convention on the Prevention and Punishment of the Crime of Genocide” (the "Genocide Convention”). The report found evidence of gross violation of human rights and systematic racial discrimination that continued after Australia had endorsed the United Nations Declarations of Human Rights

4 Tony Birch, “ 'I Could Feel it in My Body’: War on a History War,” Transforming Cultures Journal 1, no. 1 (2006), 19.

5 Tony Birch, “ 'The First White Man Born': Contesting the 'Stolen Generations' in Australia,” in Imagining Australia: Literature and Culture in the New World, eds. Jan Ryan and Chris Wallace-Crab (Cambridge, MA: University Committee in Australian Studies, 2004), 106.

6 Bain Attwood, "Learning about the Truth: The Stolen Generations Narrative," in Telling Stories: Indigenous History and Memory in Australia and New Zealand, eds. Bain Attwood and Fiona Magowan (Crows Nest, NSW: Allen \& Unwin, 2001), 183. 
and the abolition of racial discrimination as a member of the United Nations in 1945:

Official policy and legislation for Indigenous families and children was contrary to accepted legal principle imported into Australia as British common law and, from late 1946, constituted a crime against humanity. It offended accepted standards of the time and was the subject of dissent and resistance. The implementation of the legislation was marked by breaches of fundamental obligations on the part of officials and others to the detriment of vulnerable and dependent children whose parents were powerless to know their whereabouts and protect them from exploitation and abuse. ${ }^{7}$

From the "van Boven Principles" the report created a detailed road map for governments to follow in responding to the report. ${ }^{8}$ These principles advocated a full range of reparation measures, including restitution, compensation, rehabilitation, a formal national acknowledgment of responsibility, guarantees against repetition, measures for restitution of land, culture and language, rehabilitation of those individuals, families and communities affected, monetary compensation through a national tribunal, and an apology. These recommendations panicked Prime Minister Howard, who feared a blowout of payments consuming millions of dollars of government money. He announced that there would be no apology and no compensation payouts. Six months after the report's release, the government introduced a four-year package of \$63 million, principally to address family separation and its consequences through family support, parenting programmes and counselling services to be provided by government departments and community organisations that had been giving culturally appropriate expert services to members of the Stolen Generations for decades.

One of the Bringing Them Home Report's most controversial conclusions was that the system of forced removal and placements of Aboriginal and Torres Strait Islander children was a form of genocide:

Forcible removal was an act of genocide contrary to the "Convention on Genocide" ratified by Australia in 1949. The "Convention on Genocide" specifically includes "forcibly transferring children of [a] group to another group" with the intention of destroying the group. ${ }^{9}$

7 Human Rights, Bringing Them Home, 275.

8 Ibid., 280-314. 
Genocide is not only the mass killing of a people. The essence of genocide is acting with the intention to destroy the group, not the extent to which that intention has been achieved. A major aim of the forcible removals was to "absorb," “merge” or "assimilate" Indigenous children into mainstream Australian culture. Authorities may have also believed this was in the children's best interests; however, citing debates from the drafting of the Genocide Convention, the Bringing Them Home Report argued that a "policy is still genocide when it is motivated by a number of objectives. To constitute an act of genocide the extermination of a group need not be solely motivated by animosity or hatred." 10 This claim of genocide was inflammatory for most Australians who were ignorant of the complexities and nuances of the convention. For them, genocide signified the engineered mass race murders of the Holocaust. The finding of genocide also coalesced with the bitter history war over British colonisation on Australia's colonial frontiers-was it peaceful and benign, or violent and genocidal?

As a leading scholar of genocide, Colin Tatz made several important observations concerning genocide in the context of the Stolen Generations. He noted Australia's hysterical rejection of any association with genocide evident in debates in Federal Parliament in 1949 that ratified the Genocide Convention. Tatz cited Labor member Leslie Haylen's assertion that "the horrible crime of genocide is unthinkable in Australia . . . [this] . . . arises from the fact that we are a moral people." ${ }^{11}$ Tatz explained:

As Australians see it, we can't be connected to, or with, the stereotypes of Swastika-wearing SS psychopaths, or crazed black tribal Africans. Apart from Australia's physical killing era, there are clear differences between what those perpetrators did and what we did in assimilating people and removing their children. But, images notwithstanding, we are connected by virtue of what Raimond Gaita calls "the inexpungable moral dimension” inherent in genocide, whatever its forms or actions.

Commenting on "genocide denialism, memory and the politics of apology," Tatz noted his concern with the politics and motives of those in power and that "exploration of what propels these people might help to develop more effective strategies to deal with, or perhaps nullify, their activities.” Concerning

9 Human Rights and Equal Opportunity Commission, "Bringing Them Home Community Guide Update,” December, 2007, http//:humanrights.gov.au.

10 Human Rights, Bringing Them Home, 238.

11 Colin Tatz, With Intent to Destroy: Reflecting on Genocide (New York: Verso, 2003), 67-68. 
denialists at the highest levels of government in Australia, including "Prime Minister John Howard, two ex-state premiers, several retired senior bureaucrats, a small group of senior journalists and a quartet of academics with scholastic credentials," Tatz observed that their motives had "little in common with the Holocaust denialists but they strongly echo and parallel the Turkish denial industry." 12

Public debate reached extremes of hostility that threatened to leave the integrity of the Bringing Them Home Report in tatters. Strategies of denial and character assassination supported by the Howard government (and the counter-attacks), polarised and confused public opinion causing many to avoid the issue. In this toxic environment, the Commissioners of the Bringing Them Home inquiry, Sir Ronald Wilson and Professor Michael Dodson, and even the highly respected national Aboriginal leader Lowitja O'Donaghue OAM, were publicly vilified. This drove many Aboriginal people back into a safe but painful silence. In this context Aboriginal and Torres Strait Islander artists turned to the potent space of visual and performing arts to reflect on stories of family separation. ${ }^{13}$ Their works highlight the productive ways that Aboriginal people continue to recreate and take charge of the past: going beyond politics and divisive debate to use creative art and performance to elicit affective responses that are otherwise difficult to achieve.

Prime Minister Howard must have felt vindicated for his stance by the adverse court findings and media endorsement of two findings handed down by the courts over two high profile Stolen Generations cases: Lorna Cubillo and Peter Gunner suing the Commonwealth government for damages (1996-1999), and Joy Williams' compensation claim against the New South Wales government (1994-2000). ${ }^{14}$ Howard did not escape censure by his peers, however, and in 2000 the Senate Legal and Constitutional References Committee Inquiry roundly condemned his stance in their Healing: A Legacy of Generations Report. ${ }^{15}$ The Committee found that the government had failed the Inquiry and its recommendations, and that Howard should show proper leadership and supervision. They recommended the government begin by establishing a reparation tribunal, national memorial, national apology and a

12 Ibid., 122-23.

13 Anna Haebich, “A Potent Space: Witnessing Abuse and Violence through Visual Testimony,” in Volatile Substance: The Pressure of the Past in Ireland and Australia, eds. Katie Holmes and Stuart Ward (Dublin: Irish Academic Press, 2012), 104-24.

14 Richard Guilliatt, “Their Day in Court,” Sydney Morning Herald, November 20, 1999, http://www.smh.com.au/national/their-day-in-court-20130526-2n51u.html.

15 Senate Legal and Constitutional References Committee, Healing: A Legacy of Generations Report (Canberra: Commonwealth of Australia, 2000). 
national summit. Only a memorial to the Stolen Generations was added to Reconciliation Place in Canberra in 2004.

When, after 11 years, Labor Prime Minister Kevin Rudd finally delivered a national apology to the Stolen Generations, it was stripped of the international human rights contexts that laid such heavy responsibilities on the nation. These were conveniently forgotten, allowing the luxury of expressing sorrow and remorse to the Stolen Generations without the threat of unpaid debts. The word genocide was not mentioned. Most Aboriginal people generously accepted the apology as a gesture of goodwill. No Australian government, before or since, has seriously attempted to address the moral obligations imposed by the charges of genocide and gross violation of human rights. No definitive action has been taken to stop separations. The nation has continued on, largely untroubled by the debts still owed.

\section{Reflecting on Aboriginal remembering and activism}

Here I call up some of the past that Tony Birch reminds us was left for Aboriginal people to "carry alone." The past discussed here is the many decades of activism by Aboriginal leaders and families battling to save their children. This history recounts the protesting and lobbying over many decades, a significant backstory to the Inquiry in 1995 and the Bringing Them Home Report. This is still relatively unknown outside of Aboriginal communities. There are important reasons to document these narratives of activism treasured by local Aboriginal communities but lost in the fog of colonial amnesia. The retelling honours the achievements of people who had to fight for their rights against insurmountable odds and at great personal cost, often without achieving their goals and being punished for their efforts instead. These stories of courage, creativity and ingenuity can inspire community pride and further action. There are lessons to learn from strategies for change that draw on Aboriginal values, knowledge, experience and ways of working together for cultural healing. These narratives may be from the past but they resonate with experiences of injustice today. It is a truism that the past is never past in the recycling of injustices to settler colonies like Australia.

Patrick Wolfe argues that settler colonialism is not a distant moment in history but is very much part of the present: “. . . settler colonialism is a structure, not an event." 16 It is a force set in motion to possess the land and its resources, to exterminate or assimilate Indigenous peoples and their cultures,

16 Patrick Wolfe, Settler Colonialism and the Transformation of Anthropology: The Politics and Poetics of an Ethnographic Event (London: Cassel, 1999), 163. 
and to replace them with settler populations and colonial governance and culture. I add that Indigenous child removal is integral to both. There is some room for movement in the system: settler colonialism can fluctuate-it consolidates and then kilters off centre, opening opportunities for change, only to seek equilibrium again. Activists learn to act quickly; they can achieve incremental change but the pendulum always swings back to the rigid centre. In the meantime, they continue the groundwork for change.

Relocating entire communities to missions, settlements and reserve camps has been colonial main business for centuries and activists have resisted and protested in many ways against this intention to erase Indigenous populations from the colonial landscape. Documenting this in Nyungar country I used the term "incremental genocide" to describe governments' cumulative punitive initiatives and bungled outcomes that added to community racism and pushed officers to ever more drastic interventions, culminating in the 1930s in the genocidal policy of biological absorption to make the unwanted population disappear altogether. ${ }^{17}$ There are many parallels with Raphael Lemkin's "techniques of genocide" that aim to destroy the "essential foundations of the life" of human groups but not as a "coordinated plan,"18 and also with Tony Barta's account of "inevitable rather than intentional" consequences of "genocidal relations" inherent in settler colonialism that make coexistence impossible. ${ }^{19}$ Yet the Nyungar protest continued, even in this travesty of human rights, by resisting removals, escaping from institutions, writing letters and petitions and keeping culture and memories alive in covert gatherings. At Carrolup in the late 1940s the children began creating sophisticated art works with potent new meanings and messages for settler audiences, in the manner of the artists mentioned earlier. An official report in 1949 described their living conditions as "barbarous," "most unsatisfactory,” "unhygienic,” “evil smelling,” “wholly inadequate," and "needs immediate rectification." In these sorry circumstances the children created beauty in pastel and acrylic works that recalled their memories of life in bush camps with their families and landscapes from rambles in the bush around the settlement. They started the Carrolup art movement and left enduring symbols for the Nyungar nation and the Stolen Generations.

A consequence of assimilation policy from the 1950s was the foundation of an expanding new industry of government departments and non-government agencies working with Indigenous children and families that brought greater

17 Cited in Anna Haebich, “ 'Clearing the Wheat Belt': Erasing the Indigenous Presence in the Southwest of Western Australia,” in Genocide and Settler Society: Frontier Violence and Stolen Indigenous Children in Australian History, ed. Dirk Moses (New York: Berghahn Books, 2004), 267-89.

18 Ibid., 268.

19 Ibid., 270. 
surveillance of family life and more interventions to remove the children to missions, foster homes and for adoption. One family's experiences of the loss and abuse of their children led to decades of trying to bring their children home. In 2013 the family finally exposed their sorrows to public scrutiny in a compensation case in Perth that showed the tenacity of official attitudes. The elderly litigants, Donald and Sylvia Collard, explained to the court how in 1959 Child Welfare officers took their baby from the local hospital without their knowledge or consent, and two years later eight more of their children were taken into state care. ${ }^{20}$ They were seasonal rural workers living in a camp on the edge of a wheat belt town. Collards' lawyers argued that the state government had breached its obligations and duty of care to the family and in the process denied their children their biological parents, their natural familial relationships and their cultural heritage, and that the children were exposed to various forms of abuse, including isolation and trauma. The government argued it was "in the children's best interest.” Mr. Collard told the court it was due to racism, not "squalor and neglect." They had lived in a racist society with no Aboriginal Legal Service or any way to plead for their rights; "they had no-one and nowhere to turn to."21 The case was dismissed. The court ruled that the removals and wardships were reasonable by standards of the time and made for the children's welfare; that the state was not subject to the fiduciary duties alleged; that there was insufficient evidence of a policy of assimilation using the wardship of children to force Indigenous people into white Australian society; and that "all the decisions were in regard to their welfare."

The decade of the 1970s marked a turning point for activists to make Aboriginal child removals a public issue. This came about through a combination of new policies of self-determination and renewed Aboriginal activism, collaborations with non-Aboriginal supporters in positions of authority, and an interested media following the 1967 referendum, all of this culminating in 1979 in the United Nations International Year of the Child. Of several controversial cases in the media, it was events in Darwin in 1973 that exposed polarised opinion about the placement of Aboriginal children with white fos-

20 Gerry Georgatos, “ 'Nothing to Live For,' Said Stolen Generations Father,” Stringer Independent News, February 15, 2013, http://thestringer.com.au/nothing-to-live-for-said-stolen-generations-father-3-444\#.VhdE1qSEJJM; Gerry Georgatos, "WA Supreme Court in an Unbelievable Decision Dismisses Stolen Generations Compensation Claim,” Stringer Independent News, December 29, 2013, http://nationalunitygovernment.org/content/wa-supreme-court-unbelievable-decision-dismisses-stolengenerations-compensation-claim.

21 "WA Supreme Court Dismisses Stolen Generation Compensation Claim Launched by the Collard Family," ABC News, June 10, 2015, http://www.abc.net.au/news/2013-12-20/stolen-generations-test-case-dismissed-inwa-court/5169640; "Stolen Generation Family Ordered to Pay Costs After 'Test Case’ Fails in WA,” ABC News, May 9, 2015, http://www.abc.net.au/news/2015-05-09/stolen-generation-family-must-pay-court-costs/6457256. 
ter families. ${ }^{22}$ Bill Ryan, Director of the Northern Territory Legal Service and a member of the Stolen Generations, together with social worker John Tomlinson, audaciously removed an Aboriginal girl from foster care in Darwin without official permission, boarded a small plane and returned the girl to her family in a remote community. The media endorsed the department and foster parents who had detained the girl for six and a half years despite the fact that she was not a ward of the state and her parents' repeated requests for her return. Headlines exposed the depths of public ignorance, fantasising the forced return of a "civilised miss" to a "stone age world" and marriage to a middle-aged "promised husband." The then Minister for Aboriginal Affairs in the Whitlam government, Gordon Bryant, showed a refreshing new stance when he announced that he would return all Aboriginal children in foster care in the Northern Territory to their families. Nothing came of this and in the end, Bryant, Ryan and Tomlinson were punished for their actions: Bryant was dropped from the ministry, Ryan was dismissed as Director of the Aboriginal Legal Service, and Tomlinson was demoted. The girl disappeared from the newspapers but Aboriginal leaders continued to protest. In 1974 Joe McGinness, President of the Federal Council of Aboriginal and Torres Strait Islanders, called the official equating of Aboriginal family life with neglect "an absolute insult to the Aboriginal people of Australia." The new National Aboriginal Consultative Committee demanded an inquiry into fostering of Aboriginal children, but the matter was shelved.

Public memory of these sensational events may have been short but other important structural changes were happening on the ground in new Aboriginal community service organisations. They were blazing a trail of activism that would lead to the 1995 Inquiry. Legal representation by Aboriginal Legal Aid Services meant that parental rights could now be supported in court. In a landmark case in the Northern Territory Supreme Court in 1972, the judge ruled in favour of returning a two-year-old boy placed with American foster parents to the "love of his mother and extended family in which, as he grows older, he will probably feel more at home than with a white family."23 In Melbourne, the Victorian Aboriginal Legal Service (VALS) documented high rates of breakdown in adoptions of Aboriginal children-90 per cent before 1977—and related youth incarceration. ${ }^{24}$ Collaboration between Molly Dyer from VALS and the National Adoption Conference, which led opposi-

22 Anna Haebich, Broken Circles: Fragmenting Indigenous Families, 1800-2000 (Fremantle WA: Fremantle Arts Centre Press, 2000), 592-600.

23 Anna Haebich and Steve Mickler, A Boy's Short Life: The Story of Warren Braedon/Louis Johnson (Perth: University of Western Australia Publishing, 2013), 46.

24 Haebich, Broken Circles, 601. 
tion to forced adoption within white families, gave impetus to efforts to stop forced Aboriginal adoptions. The lead up to the 1979 International Year of the Child helped to progress the policy of indigenising child and family welfare through vital meetings held with Indigenous organisations in the United States and Canada funded by the federal Office of Child Care. By the late 1970s a range of Aboriginal organisations-Aboriginal Child Care Agencies, Link-Up and the Secretariat of National Aboriginal and Torres Strait Islander Child Care (formed in 1981) ${ }^{25}$ — were already assisting with family reunions, placements with Indigenous families, programmes for family maintenance, and policies to sustain Aboriginal families and cultures. In 1986 the Australian Law Reform Commission recognised Aboriginal customary family law. By the 1990s the Aboriginal Child Care Placement Principle was operating in some jurisdictions.

The impetus for a government inquiry grew into a movement of lobbying and political activism during the 1990s. In 1991 the Royal Commission into Aboriginal Deaths in Custody announced causal links between child removal and deaths in custody and alarming statistics of Aboriginal and Torres Strait Islander incarceration. In the following year Prime Minister Keating acknowledged that "we took the children from their mothers" in his now iconic speech at Redfern in Sydney. A large gathering at the 1994 Going Home Conference in Darwin announced that "public ignorance of the history of forcible removal of Aboriginal children was hindering the recognition of the needs of its victims, their families and the provision of services."26 In May 1995, the Keating Labor government appointed Sir Ronald Wilson and Professor Michael Dodson of the Human Rights Commission to lead the federal Inquiry into the Separation of Indigenous Children from their Families.

\section{Reflecting on white Australian forgetting}

Most Australians claimed to be ignorant of practices of Aboriginal child removal exposed by the Bringing Them Home Report. "I'm sorry I just didn't know," sobbed a woman at the 1997 National Adoption Conference in Perth. ${ }^{27}$ Her heartfelt cry was echoed around the country. Inga Clendinnen, delivering her Boyer Lecture Series True Stories in 1999, confessed, “I didn’t know anything about the policy.”28 The claim not to have known is puzzling. Certainly,

25 Ibid., 600-11.

26 Coral Dow, "Sorry: The Unfinished Business of the Bringing Them Home Report," Social Policy Section, Parliament of Australia, February 4, 2008, http://www.aph.gov.au/About_Parliament/Parliamentary_Departments/Parliamentary_Library/pubs/BN/0708/BringingThemHomeReport.

27 Haebich, Broken Circles, 563. 
compelling forces operated to maintain social distance and limit the flow of information. In most states and territories segregation had been enforced by a combination of legal sanctions and informal "caste barriers." These barriers, however, were never impermeable. They were cut across by relations with employers, shopkeepers, police and bureaucrats reporting to their ministers, while the press picked up on the details. Child removals were discussed in the public domain from early times and, as we have seen, there were sometimes passionate public debates. There seemed to be a pattern of recurring surges of "waking out of [and back into] forgetfulness," to paraphrase Roland Barthes. ${ }^{29}$

This conundrum of otherwise informed people "not knowing" that emerged publicly in response to the report has driven my studies of institutionalised denial, national forgetting, ignorance and racism, to find out, not as Henry Reynolds asked "Why weren't we told?," but how so many people could claim not have known about the Stolen Generations. This collective Australian amnesia seems particularly cruel in the context of denialists' rebuttal and derision of Stolen Generations' remembering of their own personal experiences of trauma.

Australians' ability to forget when it comes to Indigenous history has not gone unnoticed by scholars. In his 1968 Boyer Lectures W.E.H. (Bill) Stanner described this as:

a structural matter, a view from a window which has been carefully placed to exclude a whole quadrant of the landscape. What may have begun as a simple matter of forgetting of other possible views turned under habit and over time into something like a cult of forgetfulness practised on a national scale. ${ }^{30}$

More recently Tatz wrote of the "major tributary of forgetting, which claim[s] that there was nothing to remember in the first place." ${ }^{31}$ Raimond Gaita argued that in the past colonists were "often culpably ignorant of the wrong done to Aborigines because, in racist ways, they were blind to their full humanity.”32 There are also insights from studies of bystander amnesia and denial of genocide in post-war Germany; for example, the seemingly contradic-

28 Inga Clendinnen, “Lecture 4: Inside the Contact Zone,” True Stories: Boyer Lectures, ABC Radio National, December 5, 1999, http://www.abc.net.au/radionational/programs/ boyerlectures/lecture-4-inside-the-contactzone-part-1/3562462\#transcript.

29 Haebich, Broken Circles, 565.

30 W.E.H. (Bill) Stanner, After the Dreaming: Black and White Australians - An Anthropologist's View (Sydney: Australian Broadcasting Commission, 1968), 24-25.

31 Cited in Anna Haebich, “ 'Between Knowing and Not Knowing': Public Knowledge of the Stolen Generations,” Aboriginal History 25 (2002), 75.

32 Ibid., 71. 
tory comments of Gordon Horwitz that "genocide cannot happen without a majority of passive bystanders" and of Jean Baudrillard that "forgetting the extermination is part of the extermination itself."33

In his analysis of national collective memory, Paul Connerton argues that forgetting encompasses several different functional processes. I adapted his analysis to explore how the processes might seek to erase collective memory of the Aboriginal past: the powerful master narratives that extolled white progress and denied Aboriginal humanity; the ruthless practices to force Aboriginal people to forget their own histories of activism; the pressures to forget injustices that challenged the nation's history and identity; the public's overt concern and then desire to forget injustices that seemed to be distant and yet their responsibility; and their turning away so that the issue remained forever unresolved. ${ }^{34}$ It was, however, Nancy Tuana's discussion of the social significance of ignorance and Charles Mills' analysis of the racial contract that made the link for me between forgetting, ignorance, racism and behaviour. Tuana argues that ignorance is not a simple matter of failure or omission, an absence that we will overcome as we push out the boundaries of research and experience. Rather, it is "often constructed, maintained, and disseminated and is linked to issues of cognitive authority, doubt, trust, silencing, and uncertainty." 35 To our analyses of why we know we should add epistemologies of ignorance to account for our lack of knowledge about particular phenomena.

Looking at the Stolen Generations I could see that forgetting and ignorance are never benign: they both do things. ${ }^{36}$ Ignorance breeds in a forgetful climate of not knowing by bestowing value on misinformation and failing to question its truthfulness. In a world of separation and suspicion of the other, hearsay and imaginings can easily become fact. Repeated by government and the media, misinformation assumes an aura of authority and authenticity. Specific groups can be defined and stereotyped on the basis of these misinformed attributes, which can then be used to rationalise and normalise discriminatory treatment of members of the group. There is an easy slippage between a mindset that promotes the distancing and dehumanising of racial groups, and the acceptance and normalising of their unequal treatment. In the process, discriminatory practices become normalised to the extent that they are rendered unremarkable and virtually invisible to the wider society, even as they may as-

33 Ibid., 73.

34 Anna Haebich, "Forgetting Indigenous Histories: Cases from the History of Australia's Stolen Generations,” Journal of Social History 44, no. 4 (2011), 1035.

35 Ibid., 1035.

36 Ibid., 1036. 
sume increasingly harsh forms. Large numbers of people can tacitly support these processes without fully acknowledging the meaning of what they are doing. This is not peripheral but is an integral part of the oppression of others to which they contribute directly or indirectly. This state is powerful and obstinate, persisting in the face of circulating knowledge, observable evidence, personal encounters and even public protests that might emerge. Mills argues that these steps lead to the "ironic outcome" where the perpetrators of prejudice and discrimination "fail to recognise or understand the conditions that their racism has helped to produce." ${ }^{\text {37 }}$ Tatz provides an astute link from this analysis back to racism in Australia:

In South Africa I studied "native policy.” On arrival here in 1961, I studied “ Aboriginal policy." People who know of my dual interest still ask me, "Is it true to say that Apartheid was a malevolent instrument of racial oppression, whereas racism in Australia was a form of ignorant innocence, or innocent ignorance, an inability to understand or respect indigenous culture and values, albeit with some nasty consequences?” Comparisons aside, how does one categorise Australia's race relations? Much of that interracial history I call genocide. ${ }^{38}$

\section{Removals keep on happening}

The emotional upheaval, shock, grief, guilt and outrage about the Stolen Generations might now be part of national history, but in public memory it is once again slipping into the morass of forgetting and ignorance. For many politicians and bureaucrats the 54 recommendations of the Bringing Them Home Report are but a dim memory. Tragically, the breaking up of families keeps on happening. Despite ongoing activism to reclaim the children and re-indigenise child and family care, removals and placements outside of Aboriginal and Torres Strait Islander families are accelerating. The Aboriginal Child Care Placement Principle is increasingly sidelined in care arrangements. Placements such as forced adoption, rejected in the 1980s, are being reconsidered. A central Aboriginal family childcare arrangement of grandmothers caring for grandchildren is once again under scrutiny, prompting the formation of the protest group Grandmothers Against Removals (GRMAR). In a further cruelty, some newborn babies are taken from mothers who test drug

\footnotetext{
37 Cited in Haebich, "Forgetting Indigenous," 1036.

38 Colin Tatz, Genocide in Australia, Canberra: Australian Institute of Aboriginal and Torres Strait Islander Studies, Research Discussion Paper Number 8, 1999, 28-32.
} 
positive, despite care being available within the mothers' extended family. Aboriginal mothers are also being imprisoned at unprecedented rates, leaving their children vulnerable to removal from their families. Incarceration of young people increases along with instances of their abusive treatment. A public outcry was raised by shocking images of abusive treatment of Aboriginal youths at the Don Dale Detention Centre in the Northern Territory in 2016 on ABC's Four Corners, now the subject of a Royal Commission into the Protection and Detention of Children in the Northern Territory. Despite public outcry about such incidents, the National Sorry Day Committee found in its Bringing Them Home Scorecard Report 2015 that there is still "insufficient recognition of the trauma, loss and grief" experienced by members of the Stolen Generations and the "impacts on health and wellbeing."39

In her programme for Perth Noongar Radio that won the 2014 Human Rights Award for Radio, Yamatji radio producer and foster care mother Carol Dowling cited alarming figures from Western Australia where Aboriginal children make up 50.5 per cent of all children in out-of-home care in the state but are only five per cent of the general population. ${ }^{40}$ Of these, 34 per cent are with non-Aboriginal carers. In an example of "bad policy economics" she claimed that expenditure to keep child protection structures in place was 50 times more than that spent on Aboriginal family support mechanisms to help keep children in their families. Dennis Eggington, Director of the Aboriginal Legal Service, insisted that funding should be relocated to holistic Aboriginal-run services to provide housing and relieve poverty, causes that lead to removal of Aboriginal children. Selena Kickett from the Dumbartung Aboriginal organisation in Perth spoke of the vital need for healing to relieve the trans-generational trauma from the ongoing break up of Aboriginal families. An unidentified mother cries out that taking the children is "killing our future." Little wonder then that Dowling named the programme "Another Stolen Generation."

How can we explain the continuing punitive agendas and policies? We know of the years of Aboriginal activism and their achievements in David and Goliath battles against the full force of the settler colonial state. Yet punitive discourses, policies, legislation and bureaucracies continue to protect and advance stakeholder interests in Indigenous land and sea, and institutions that employ thousands of people maintain control over Aboriginal people. The paradigm of Aboriginal families as sites of danger and risk for their children

39 John Rule and Elizabeth Rice, Bringing Them Home Scorecard Report 2015 (Canberra: National Sorry Day Committee, 2015), 8.

40 Carol Dowling, “Another Stolen Generation,” Noongar Radio, September 18, 2014,

https://www.cbaa.org.au/article/another-stolen-generation-noongar-radio-perth. 
continues to be rolled out to endorse ongoing removals and to raise public support for stricter levels of government intervention and management, ostensibly to improve health and wellbeing. The Federal Government used allegations that child sexual abuse was rife in Indigenous communities to validate the invasive actions of the Northern Territory Intervention. The West Australian government made similar claims in threatening to close up to 150 communities. The forced removal of Aboriginal children remains an integral process of the Australian settler colony.

The shift from principles of Aboriginal and Torres Strait Islander self-determination and pluralism represents yet another iteration of Wolfe's model of the settler colony, now fuelled by neoliberal ideologies and practice. ${ }^{41}$ Events in today's neoliberal times represent another return to the status quo, to the familiar scenario of economic and political anxieties, antipathy to the welfare state, demands for Aboriginal lands and resources, and the use of instruments of settler colonialism to restore the balance of colonial supremacy and progress. Terri Libesman points to the accumulated consequences for Aboriginal families, of the shifts away from recognition of collective histories and rights to a more neoliberal focus on individual responsibility and compliance with mainstream measures of wellbeing. ${ }^{42}$ This shift has been accompanied by greater prevalence of populist racist characterisations of neglect and abuse as pertaining to cultural and individual Indigenous deficits rather than founded in colonial experiences and systemic disadvantage. There has also been more anecdotal evidence about a disregard for the rule of law and more overtly discriminatory responses to Indigenous families.

We now live with escalating alarms of global terrorism, climate change, economic disaster and wars of human annihilation. Fears of so-called problem populations-Indigenous, ethnic, refugees and asylum seekers-threaten national security and peace. In this context, there is support for an encompassing state apparatus of management through surveillance, containment and banishment to institutions and/or forced assimilation into the nation state. Global terrorism generates dehumanising of "problem populations" and support for harsh solutions that hark back to carceral institutions for Indigenous populations in settler colonial states. This is the reality of accelerating incarceration of Indigenous men, women and children. For Indigenous people, the driving force of neoliberal capitalist economies for global development engages them in new struggles against global organisations to maintain their hard-won land

41 The following argument draws on Anna Haebich, "Neoliberalism, Settler Colonialism and the History of Indigenous Child Removal in Australia,” Australian Indigenous Law Review 19, no. 8 (2015/2016), 21-22.

42 Terri Libesman, email message to author, March 12, 2015. 
security and protect precious resources of water, food, minerals and energy from fast growing markets and populations. Labelled as problem populations they once again face threats of being displaced, relocated and forced to transition culturally by assimilating into the mainstream.

The model of settler colonialism presented in this essay suggests a continuing draconian settler colonial state with no end to the forced removal of Aboriginal children. As we have seen, however, there is some hope in the narratives of activism and strategies for change drawing on Aboriginal values, knowledge and experience and ways of working together for cultural healing. Freed from the strictures of government policy and bureaucracy, the Stolen Generations and their supporters can create movements of people working together with open hearts and minds to heal the past. In 2015 the National Sorry Day Committee advised that "the best sources of knowledge and understanding of the backgrounds and needs of the Stolen Generations are the Stolen Generations themselves.” They are also the people best placed to drive what is needed now and into the future. 